\title{
Copyright issue on music back sound usage by Indonesian YouTuber
}

Xenia Angelica Wijayanto

LSPR Communication and Business Institute, Jakarta, Indonesia

Email:xenia.aw@lspr.edu

Lestari Nurhajati

LSPR Communication and Business Institute, Jakarta, Indonesia

Email: lestari.n@lspr.edu

\begin{abstract}
According to We Are Social research in January 2018, Indonesia's population now is 265,4 million, while its social media active users reached 130 million. $43 \%$ of people are using Youtube as their primary social media. This situation shows us that Youtube is still the most used and liked social media channel, followed closely by Facebook and Whatsapp. The vlogger phenomenon is also getting stronger among Indonesian young people. The increasing number of Youtube content production ranged from artists, public figures, and ordinary people, also known as Youtuber. One of the famous Youtuber is Raditya Dika, whose subscriber reached more than 3.3 million, and estimated income per year around USD 46 thousand to USD 739 thousand. The problem that arises is about the copyright violation in background music used by Indonesian Youtuber. This research tries to dig further data about the youtube policy in protecting the copyright issue in that area. This research uses a discourse analysis method on 15 videos from the top 5 Youtuber in Indonesia as the unit
\end{abstract}


of analysis. The result shows that some Youtuber still violate the copyright issue while using background music on their Youtube materials production.

Keywords: Copyright Issue, Music, YouTuber, Discourse Analysis

\section{Introduction}

According to We Are Social research in January 2018, the number of Indonesia's population right now is 265,4 million people, while the number of Indonesia's social media active users reached 130 million people. YouTube is social media with the highest user in Indonesia. This statement reinforced by a statement issued by Google that there are 50 million active YouTube users per month from a total of 146 million internet users in Indonesia, with average use per day is 42.2 minutes (Ayuwuragil, 2018). Based on research conducted by Google along with TNS, Google says that 57 percent of YouTube users are looking for entertainment content, and 86 percent also accustomed to visiting the site to learn new information (Praditya, 2018). In the same research, also mentioned that YouTube is the first platform used by Indonesians when looking for video content. It can seem that at this time, YouTube can say to start shifting the position of conventional television as a place for people that are looking for entertainment. The increasingly diverse and compelling YouTube content causes a large number of Indonesians to spend time on YouTube.

Veronica Utami, Head of Marketing at Google Indonesia, stated that Indonesians not only there to see international content on YouTube, but they are also very proud of local creators who can interact in an understandable and appropriate language for them (Praditya, 2018). Of course, this seen from the number of content makers from Indonesia who have a YouTube channel with many subscribers. To appreciate the content creator that has many subscribers, the YouTube award them with a gold play button. Gold play button obtained when the content creator has more than 1 million subscribers. The content creator from Indonesia, or usually we are familiarly called them as 'Youtuber' who gets the gold play button, is currently increasing.

Other than that, YouTube is also where the YouTubers make a profit. Due to the considerable income earned from YouTube, a new profession, 'Youtuber,' is emerging. The more their subscribers and their video viewers, the higher will be their profits. Therefore, Indonesian content creators are 
competing to make more creative and exciting content to be able to entertain as many viewers as they can on their YouTube channel and video. Based on data from CNBC Indonesia, the following are the top-ranking Youtubers with the highest income and subscriber of Indonesia (Yulistara, 2018).

Table 1. top-ranking Youtubers with the highest income and subscriber of Indonesia

\begin{tabular}{|c|c|c|c|}
\hline $\mathrm{NO}$ & Name & Subscriber & Income \\
\hline 1 & Raditya Dika & $3,3 \mathrm{M}$ & US\$ 46.000 - US\$ 739.000 \\
\hline 2 & Ria Ricis & $2,7 \mathrm{M}$ & US $\$ 90.000$ - US\$1.400.000 \\
\hline 3 & Arief Muhammad & $1 \mathrm{M}$ & US\$ 13.000 - US\$217.000 \\
\hline 4 & Gen Halilintar & $2,3 \mathrm{M}$ & US\$ 175.000 - US\$2.800.000 \\
\hline 5 & Kevin Hendrawan & $746 \mathrm{~K}$ & US\$ 12.000 - US\$ 193.000 \\
\hline 6 & Bayu Skak & $1,4 \mathrm{M}$ & US\$20.000 - US\$317.000 \\
\hline 7 & Reza Oktovian & $1,8 \mathrm{M}$ & US $\$ 27.000$ - US $\$ 434.000$ \\
\hline 8 & Edho Zell & $1,8 \mathrm{M}$ & US\$33.000 - US\$522.000 \\
\hline 9 & Young Lex & $748 \mathrm{~K}$ & US\$26.000 - US\$ 411.000 \\
\hline 10 & Ini Vindy & & US\$15.000 - US\$203.000 \\
\hline
\end{tabular}

Source: Social Blade, data taken from CNBC Indonesia, processed by the author.

What YouTube does is throw new light on the communicative entitlements of broadcasting. These now seem to be hierarchical and constraining by comparison with the affordances of YouTube. However, YouTube (and it is, of course, one of many such sites) highlights the restricted position and participatory constraints placed on the ordinary person in that regime. Broadcasting created modern public life as spectacle, as 'media events' and as topics for discussion, but it did not distribute the means of creative production to users, nor did it invite the labor of 'co-creation.' There are then limits to the kind of citizenship offered by broadcasting by comparison to that imagined by YouTube (Tolson, 2010).

In the meantime, there is no official data on YouTube income counting technique, but at least we can make estimation when 1000 viewers see a video on YouTube, the Youtuber will earn around $\$ 1(=\$ 1$ per 1000 views) (How Much Money do YouTubers Make per View, 2018). This amount not included with the income that comes from product endorsement or services offered to 
the Youtuber.

YouTube videos and music is inseparable. Interesting YouTube content usually equipped with supporting music. On its website, YouTube provides suggestions for how to properly manage the YouTube channel content to bring in more viewers and subscribers. According to YouTube, "The right music can make a moment more meaningful." They also say to find the perfect music to reach the hearts of the viewers. (Creatoracademy.youtube.com, 2018). Many YouTube videos have good song content from their original creators, as well as from those who reproduce a song called cover songs. The songs on YouTube are an essential key in explaining video effectiveness. When someone watches the video for the first time, they might hope to see something entertaining. The musical and visual elements of a video initially performing the effectiveness message reach the audience (Filardo-Llamas, 2015).

The problem that arises is about the violation of the copyright in background music that is used by Indonesian Youtuber. This research tries to dig further data about how YouTube policy protecting copyright issue in that area, and also how the Youtuber apply the copyright attribution on their videos.

\section{Literature Review}

\section{Copyright Issue on Social Media}

Based on Law of the Republic of Indonesia Number 28 of 2014 on Copyrights, copyright means an exclusive right of the author vested automatically based on declaratory principle after Works embodied in a tangible form without reducing under restrictions by the provisions of laws and regulations. This law is made by the consideration that the development of scientific, technological, artistic, and literary works has been so rapid. It is necessary to have more reliable protection and guarantee legal certainty of Authors, Copyright holders, and Related Rights owners, as stated in the opening of Copyright Law. Copyright protection is an automatic protection. However, there's some rights that suggested to be registered, especially when the creations are potentially to have economic values.

The copyright law in Indonesia covers a great deal of three things: scientific, artistic, and literary works. In art fields, the issues to be discussed in this paper, there are many violations of copyright. Many found copyright infringement in the field of music. Not just that, according to the data obtained 
from Indonesia National Police Headquarter on 26/01/2014, between 2011 and 2013, there was an increase of IPR infringement cases in Indonesia, especially copyright infringements. In 2011 there were 209 cases of infringements with 258 suspects. In 2012, the infringements increased up to 338 cases, with 309 suspects (Triyanto, 2017).

There is frequent copyright infringement on the use of music and songs, especially in broadcast media (radio and television), as well as in entertainment venues. Some time ago, Yayasan Karya Cipta Indonesia (KCI) had found copyright infringement in the form of song usage in karaoke Inul Vizta Manado. This case also tails long because it goes into the legal path until the foundation finally won the case.

YouTube, as social media with the most users in Indonesia, has excellent potential for copyright infringement. One of the most prominent cases in 2007 is when Universal Records successfully asked YouTube to remove a video that used Prince music without their permission. In February 2007, Stephanie Lenz uploaded to YouTube a short song from "Let's Go Crazy." A series of legal actions followed by Universal's record and music publishing companies request that YouTube have to remove the clip, using the 2000 Digital Millennium Copyright Act (DCMA) (Laing, 2012).

Following this case, YouTube, through its website and channel, started to openly distribute rules regarding the correct use of copyright following government regulations that are applicable globally. The rules on copyright generally have the same roots internationally, so that it can see that there are significant similarities in the regulation in most countries. However, because of the unique nature of social media, YouTube makes its own rules, which are an adjustment of the WTO treaty adopted by joined countries. More on this can be seen on the link https://creatoracademy.youtube.com/page/ lesson/copyright-usage and https://www.youtube.com/intl/en-GB/yt/about/ copyright/\#support-and-troubleshooting.

\section{Background Music on YouTube and Copyright}

One of the ways to build quick popularity is through becoming a Youtuber. So, no wonder that many young people are looking for a shortcut to popularity by producing various events that are uploaded via YouTube. Those people with such popularity, often known as social media celebrity/Youtuber/ Vlogger. They act like real celebrities, although they are often known only as a 
social media celebrity. Further understanding about building online popularity can also inform us about the inherent social significance of new types of celebrities who, even as 'just online celebrities,' unknown to the public at large, appear to embody the same societal and cultural roles as mainstream celebrities (García-Rapp, 2016).

The YouTubers in producing videos on their YouTube channels can upload different types of programs. Starting from the beauty review, travel journey, games, until the daily activities like making a video diary. In some videos, it even shows only monologue from the Youtuber (Gannon \& Prothero, 2018). From these conditions, it can be seen that being famous and becoming a celebrity via YouTube is relatively easy to do, especially on people who have potential, talent, and hobbies in specific fields as well as diligent in making videos and uploading them to YouTube.

The development of technology is very rapid, allowing all parties to produce videos on YouTube very quickly. It included the increasing number of ways and production tools used by young people or anyone and not necessarily professional video workers. Some tools allow them to easily create digital artwork, make movies that posted to YouTube, and record music using programs such as GarageBand on Mac (Thibeault, 2012). In video YouTube videos, music (as background or as the main component) becomes one of the main strengths of the show. Not infrequently, YouTube viewers commented on the use of background music from the positive side (nice to hear, fit the visual, ask the title of the song, and others) and the opposite (negative judgment). However, that is the basic idea of YouTube: as a recreational tool, primarily used for amusement, diversion, and fun (Vergani \& Zuev, 2011).

Some highlights in this paper are the YouTube policy about the use and attribution of copyright on their content, especially the use of music either as background music or as the main component of video content. YouTube implements several categories in its copyright protection as embodied in its website. One of them is about the use of free content such as Creative Commons license or through CC site that gives so much free content with various attribution and also some other sites that support free content. For further protection, YouTube implements protection such as Content ID claim, fair use/fair dealing, and Copyright Strike Basic that explained below.

Content ID claims is a condition when uploading a video that contains copyright-protected material; the content owner can use a Content ID claim. These claims are issued by companies that own music, movies, TV shows, video 
games, or other copyright-protected material. However, when the copyright owners do not want their material reused, they also can block a video, mute a video, or block specific platforms. (support.google.com/youtube, 2018)

Second is Copyright Strike Basic. On Google support site, it is written that When receiving a copyright strike, that means that the video has been taken down from YouTube because a copyright owner has sent a complete and valid legal request asking YouTube to do so. When a copyright owner formally notifies YouTube that they don't have their permission to post their content on the site, they take down the upload to comply with copyright law. They also say that videos can be removed from the site for different reasons, not always a copyright-related problem. (Google Support Youtube Answer, 2018)

The third is fair use. Fair use in YouTube is often misunderstood because of its broad meaning. The use of 'fair use' is defined as fair use of components that do not belong to the content creator. Often fair use issues are resolved by granting attribution by its users as a way to avoid copyright sanctions. Until now, YouTube continues to develop a fair use policy to find the right application for each case because the application varies for each case. (Youtube Copyright Protection, 2018)

\section{Methods}

This research uses a qualitative approach using discourse analysis as a data processing technique. Discourse studies should undoubtedly have more to say about this, especially given the pace of processes of globalization, where it is essential to understand not only these worldviews in themselves but also how these interact and are in transformation (Bouvier, 2015). Furthermore, our research using Vernacular Discourse by Guo \& Lee (2013) to analyze three aspects of Youtube production, there are content, agency, and subjectivity.

Unlike other video products such as films, this open-ended and collective discourse is linked and gathered around the original message, and can be monitored through the views, likes and comments that the message attracts (Rolando, Taddeo \& Beccaria, 2016). Researchers will be more detailed on the number of the subscriber, the number of likes and dislike, the number of comments, and also on when the Youtuber uploaded the video. The upload period that selected is based on recent times, recorded from April 2018 until July 2018, also whether present or not, the background music in the understudied videos. 
Next, the researcher took 5 out of 10 Youtubers stated before as the unit analysis. They are Raditya Dika, Ria Rice's, Arief Muhammad, Gen Halilintar, and Kevin Hendrawan. In detail, the 15 YouTube videos taken from those 5 Youtubers examined the existence of background music used. The categories are on the number of songs, song titles, and whether or not the inclusion of the copyright statement. To find out the background music used by the Youtuber, researchers use Shazam application on an android phone. With this tool, researchers can capture and detect the song title and name of the singer along with the album entitled. However, if the song is too short or much interspersed with conversation, the Shazam tool cannot detect it.

\section{Results and Discussion}

\section{Top 5 Youtuber in Indonesia}

From the top 5 Youtuber following the rank listed on the CNBC Indonesia website, there appears to have some significant changes. For example, in the ranking data, it is noted that Raditya Dika has the highest subscriber number in Indonesia. However, when this research conducted, his position has been replaced by Ria Ricis with account Ricis Official. Similarly, the third rank that was initially occupied by Arief Muhammad, when this study conducted, appears that Gen Halilintar has shifted Arief position.

When looking at the characters of the Youtuber studied, as the agency, it can be said that all five of them is a public figure who gain their profile because of the use of their social media. The Youtubers indirectly position themselves as different agencies then mainstream media, in this case, the television. The development of YouTube globally, indicating that the domination of mainstream audiovisual media, in the example, television, is no longer valid.

Raditya Dika, since a few years ago known as a blogger who has many fans. He wrote a book based on his blog in 2005 titled: "Kambing Jantan: Sebuah Catatan Harian Pelajar Bodoh," with the comedy genre, which also gained considerable profits, and continued with the making of several widescreen movies based on his blog as well. The man who was born in Jakarta, December 28, 1984, until 2017, had listed himself as the wealthiest Youtuber in Indonesia, which then in 2018 shifted by the fame of Ria Ricis.

Meanwhile, Ria Ricis recorded as an actual Youtuber since 2016. However, her career began as a Selebgram, a celebrity title because of Instagram. 
Not surprising that her subscriber on Youtube has reached more than 4 million people. Its nothing compared to her Instagram follower that's powerful and reached more than 9.1 million followers. Her real name is Ria Yunita, born in Batam, July 1, 1995, and now she lives in Depok, continuing her college, while her parents stay in Batam.

The next Youtuber is Arief Muhammad. Born under the name Muhammad Arief Yakoeb in Batam, October 26, 1990, Arief was previously a selebtwit with his twitter account @ poconggg, which could cause a sensation in twit world because of his phenomenal and mysterious account. Often tell jokes on twitter as an anonymous account until finally his identity is unraveled, and he starts using his real name as Arief Muhammad. Arief also wrote a book titled "Poconggg Juga Pocong" in 2011, which later filmed with the same title. After that, Arief joined with Raditya Dika, and Bena Kribo nurturing nyunyu.com site and afterward began to plunge into the world of YouTube as a content maker that shares the story of his daily life packaged with jokes. Currently, Arief is busy managing his YouTube channel and new business he started to develop in the culinary field.

The fourth Youtuber is a unique Gen Halilintar Family. This family has 11 children, six boys, five daughters, the Father (Halilintar Anofial Asmid born October 13, 1968), and the Mother (Lenggogeni Faruk, born October 29, 1972). This phenomenal Youtuber family with the tagline "My Family My Team" has traveled nearly to 100 countries bringing all its family members without a maid. They apply what they called 'homeschooling plus' education to their children due to their busy family business trip schedule. Their eldest was born in 1994, and the youngest was born in 2012. The mother (Gen) has released a book that tells about their journey in 2015 titled "Kesebelasan Gen Halilintar: My Family My Team.” They run various businesses in various countries. No wonder that this family's business travel schedule is very high. The presence of this family on Youtube can be seen since March 4, 2015.

The last Youtuber in this paper is Kevin Hendrawan, a winner of L-Men of the Year 2014. The man named Yohanes Kevin Hendrawan, who was born in Purwokerto, June 21, 1992, started his career as Mister International in 2015 before entering the world of presenters and entertainment. Since 2015 he has been active in the Youtube world and has his channel. As a Youtuber with a myriad of achievements, Kevin uploaded a lot of content science-themed, healthy lifestyle and also recounted his daily travel. With content that tends to be more severe than the other YouTubers, Kevin still has many loyal subscribers 
Journal of Social Studies (JSS), Volume 16, Number 2, 2020: 137-156

that he calls Kevinian.

In this study, there are 15 Youtube videos from the top 5 Youtuber that being analyzed. The 15 videos selected were not only seen from the novelty of the video but also considered whether or not background music and songs in the production of the video presentation. Details of the 15 Youtube videos, can be seen in the table below:

Table 2. Top 5 Youtuber's Video List

\begin{tabular}{|c|c|c|c|c|c|c|c|c|}
\hline No & Youtuber & Title & $\begin{array}{l}\text { Sub- } \\
\text { scriber }\end{array}$ & Views & Like & $\begin{array}{l}\text { Dis- } \\
\text { like }\end{array}$ & $\begin{array}{l}\text { Com- } \\
\text { ments }\end{array}$ & $\begin{array}{l}\text { Pub- } \\
\text { lished } \\
\text { on/ Du- } \\
\text { ration }\end{array}$ \\
\hline 1 & $\begin{array}{l}\text { Raditya } \\
\text { Dika }\end{array}$ & $\begin{array}{l}\text { Ketiga Kalinya } \\
\text { Naik Helikopter } \\
\text { Masih Mau } \\
\text { Muntah }\end{array}$ & $4.4 \mathrm{M}$ & $\begin{array}{l}549 \\
918\end{array}$ & $17 \mathrm{~K}$ & 467 & 1,320 & $\begin{array}{l}\text { July 27, } \\
2018, / \\
7: 54\end{array}$ \\
\hline 2 & $\begin{array}{l}\text { Raditya } \\
\text { Dika }\end{array}$ & $\begin{array}{l}\text { Suami Masakin } \\
\text { Istri! Ternyata } \\
\text { Hasilnya }\end{array}$ & $4.4 \mathrm{M}$ & $\begin{array}{c}1,339 \\
692\end{array}$ & $\begin{array}{l}40 \\
K\end{array}$ & 766 & 5,066 & $\begin{array}{l}\text { July 23, } \\
2018, / \\
15: 37\end{array}$ \\
\hline 3 & $\begin{array}{l}\text { Raditya } \\
\text { Dika }\end{array}$ & $\begin{array}{l}\text { Ciri Laki-laki } \\
\text { Stress }\end{array}$ & $4.4 \mathrm{M}$ & $\begin{array}{l}853 \\
395\end{array}$ & $\begin{array}{l}45 \\
\mathrm{~K}\end{array}$ & $\begin{array}{c}2,1 \\
\mathrm{~K}\end{array}$ & 3,236 & $\begin{array}{l}\text { July 13, } \\
2018, / \\
3: 03\end{array}$ \\
\hline 4 & $\begin{array}{l}\text { Ricis } \\
\text { Official }\end{array}$ & $\begin{array}{l}\text { Akhirnya Naik } \\
\text { Helicopter!!! } \\
\text { Bareng } \\
\text { Awkarin? }\end{array}$ & $4.8 \mathrm{M}$ & 31,919 & $\begin{array}{c}7,1 \\
\mathrm{~K}\end{array}$ & 37 & 1,049 & $\begin{array}{l}\text { July 29, } \\
2018, / \\
11: 44\end{array}$ \\
\hline 5 & $\begin{array}{l}\text { Ricis } \\
\text { Official }\end{array}$ & $\begin{array}{l}\text { Detik-Detik } \\
\text { Orang Tak Jujur } \\
\text { Ditemukan }\end{array}$ & $4.8 \mathrm{M}$ & $\begin{array}{l}574 \\
725\end{array}$ & $\begin{array}{l}46 \\
K\end{array}$ & 372 & 2,355 & $\begin{array}{l}\text { July 26, } \\
2018, / \\
11: 23\end{array}$ \\
\hline 6 & $\begin{array}{l}\text { Ricis } \\
\text { Official }\end{array}$ & $\begin{array}{l}\text { Ricis Nyobain } \\
\text { Nge-Gym w/ } \\
\text { Shely Che }\end{array}$ & $4.8 \mathrm{M}$ & $\begin{array}{l}346 \\
363\end{array}$ & $\begin{array}{l}29 \\
K\end{array}$ & 285 & 2,957 & $\begin{array}{l}\text { July 24, } \\
2018, / \\
10: 55\end{array}$ \\
\hline 7 & $\begin{array}{l}\text { Arief } \\
\text { Muhammad }\end{array}$ & $\begin{array}{l}\text { Main Bowling } \\
\text { Bareng } \\
\text { Followers } \\
\end{array}$ & $1.4 \mathrm{M}$ & $\begin{array}{l}398 \\
457\end{array}$ & $\begin{array}{l}23 \\
K\end{array}$ & 157 & 2,796 & $\begin{array}{l}\text { July 21, } \\
2018, / \\
14: 47\end{array}$ \\
\hline 8 & $\begin{array}{l}\text { Arief } \\
\text { Muhammad }\end{array}$ & $\begin{array}{l}\text { SUMBA: } \\
\text { Hidden Paradise }\end{array}$ & $1.4 \mathrm{M}$ & $\begin{array}{l}478 \\
890\end{array}$ & $\begin{array}{l}52 \\
K\end{array}$ & 268 & 4,527 & $\begin{array}{l}\text { July 10, } \\
2018, / \\
2: 55\end{array}$ \\
\hline
\end{tabular}


Copyright issue on music back sound usage by ...(Xenia Angelica Wijayanto,Lestari Nurhajati)

\begin{tabular}{|c|c|c|c|c|c|c|c|c|}
\hline 9 & $\begin{array}{l}\text { Arief } \\
\text { Muhammad }\end{array}$ & $\begin{array}{l}\text { Vloggg \#138 - } \\
\text { Sahur Bareng } \\
\text { Anak Panti }\end{array}$ & $1.4 \mathrm{M}$ & $\begin{array}{l}494 \\
369\end{array}$ & $\begin{array}{l}26 \\
\mathrm{~K}\end{array}$ & 190 & 1,749 & $\begin{array}{l}\text { June 6, } \\
2018, / \\
9: 24\end{array}$ \\
\hline 10 & $\begin{array}{l}\text { Gen } \\
\text { Halilintar }\end{array}$ & $\begin{array}{l}\text { Pusing Muter } \\
\text { Nendang Bola - } \\
\text { Gen Halilintar } \\
\text { FIFA World } \\
\text { Cup Challenge }\end{array}$ & $3.5 \mathrm{M}$ & $\begin{array}{l}588 \\
358\end{array}$ & $\begin{array}{l}27 \\
K\end{array}$ & 575 & $2,7 .$. & $\begin{array}{l}\text { July } \\
18,2018 / \\
12: 09\end{array}$ \\
\hline 11 & $\begin{array}{l}\text { Gen } \\
\text { Halilintar }\end{array}$ & $\begin{array}{l}\text { Kegilaan } \\
\text { Sebelum } \\
\text { Performance }\end{array}$ & $3.5 \mathrm{M}$ & $\begin{array}{l}264 \\
977\end{array}$ & $\begin{array}{l}16 \\
K\end{array}$ & 170 & 1,339 & $\begin{array}{l}\text { July13, } \\
2018 / \\
15: 32 \\
\end{array}$ \\
\hline 12 & $\begin{array}{l}\text { Gen } \\
\text { Halilintar }\end{array}$ & $\begin{array}{l}\text { Pake Kostum di } \\
\text { Tempat Umum } \\
\text { Kocaaak!!! } \\
\text { Costume } \\
\text { Challange Gen }\end{array}$ & $3.5 \mathrm{M}$ & $\begin{array}{l}775 \\
469\end{array}$ & $\begin{array}{l}32 \\
\mathrm{~K}\end{array}$ & 508 & $3,6 .$. & $\begin{array}{l}\text { July } \\
6,2018 / \\
8: 58\end{array}$ \\
\hline 13 & $\begin{array}{l}\text { Kevin } \\
\text { Hendrawan }\end{array}$ & $\begin{array}{l}\text { Ngabuburit The } \\
\text { Series: Damai } \\
\text { Itu Indah } \\
\text { Episode } 29 \\
\text { (Final) }\end{array}$ & 984,161 & 48,681 & $\begin{array}{c}2,8 \\
\mathrm{~K}\end{array}$ & 34 & 595 & $\begin{array}{l}\text { June } \\
12,2018 / \\
5: 32\end{array}$ \\
\hline 14 & $\begin{array}{l}\text { Kevin } \\
\text { Hendrawan }\end{array}$ & $\begin{array}{l}\text { Kaget Lihat } \\
\text { Malin } \\
\text { Kundang Asli } \\
\text { Plus Bangkai } \\
\text { Kapalnya } \\
\text { langsung di } \\
\text { Padang } \\
\end{array}$ & 984,161 & $\begin{array}{l}189, \\
454\end{array}$ & $\begin{array}{c}7,8 \\
\mathrm{~K}\end{array}$ & 113 & $1,1 .$. & $\begin{array}{l}\text { May 12, } \\
2018, / \\
14: 59\end{array}$ \\
\hline 15 & $\begin{array}{l}\text { Kevin } \\
\text { Hendrawan }\end{array}$ & $\begin{array}{l}\text { Short Escape: } \\
\text { Jakarta Rasa } \\
\text { Gili Trawangan }\end{array}$ & $\begin{array}{c}984 \\
161\end{array}$ & $\begin{array}{l}217 \\
530\end{array}$ & $\begin{array}{c}6,3 \\
\mathrm{~K}\end{array}$ & 136 & 712 & $\begin{array}{l}\text { April 22, } \\
\text { 2018,/ } \\
\text { 16:14 }\end{array}$ \\
\hline
\end{tabular}

Source: Youtube and the data being processed by the researcher until 29 July 2018

\section{Copyright in Youtube Content Production in Indonesia}

In the following discussion, researchers will discuss copyright on background music and songs on YouTube produced by Youtuber. This discussion refers to the technique of vernacular discourse analysis related to content issues, but the content mentioned here is limited to the use of songs and background music. 
Video 1 Raditya Dika, titled: "Ketiga Kalinya Naik Helikopter Masih Mau Muntah," used two background songs that both not present the copyright attribution. The first background song titled 'Dangerous (Robin Schulz Remix),' David Guetta feat Sam Martin, while the second song, the song, and singer cannot be identified. In the second video of Raditya Dika, there are three songs, but only one identified titled 'Water Music, Suite No. 2' (Bartok Music, The top 100 Masterpieces of Classical Music 1685-1928 Volume 1). The other two songs are unidentified, and the Youtuber does not list the copyright attribution. In the third video, three songs are used to support the video, three of them without a copyright explanation from the Youtuber. One of the songs identified is 'So Quer Vrau' from MC MM feat DJ RD.

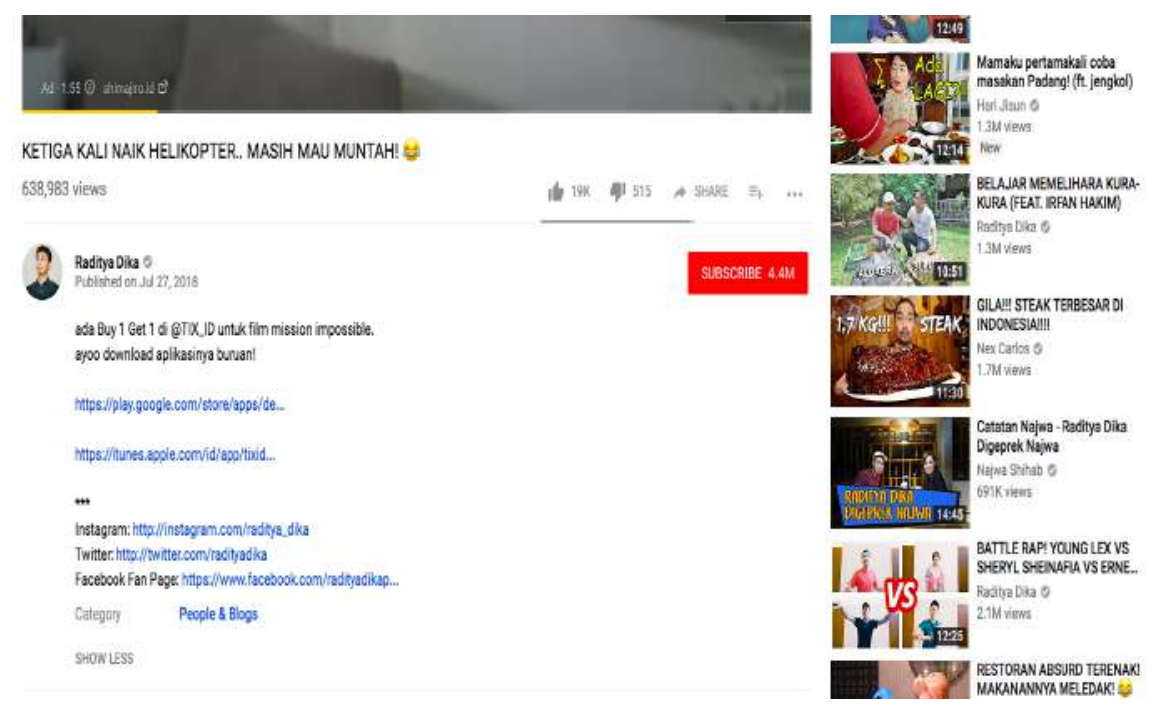

Picture 1. Sample of Raditya Dika's video

Ria Ricis a.k.a. Ricis Official's first video titled "Akhirnya Naik Helicopter!!! Bareng Awkarin?" There are five songs, and all of them do not include copyright. The first song title is unidentified. The second song that identified is 'Summer Time' (Morninglightmusic from Album Five), then the third song 'On Fire!!' by Gucci Brady. The fourth song is 'Radiance (Full Mix)' by Chris Payne from Album: Car167 Atmos 4-Nature Sea-Space. The fifth song is 'Forever Together' by Craig Ballie, from Forever Together Album. In the second video of Ricis, there are four songs, all there is no copyright. The first song was unidentified, 
the second song titled 'Caperucita Roja' by Chavitos from Album: El Mundo De Los Ninos Vol. 2. The third and fourth songs are unidentified. Ricis's third video, there are three songs. Two songs with no copyright and one song are with copyright attribution by the Youtuber. The first song titled 'Skinny Jeans' by Dan Mervis from Album: Want Your Body. The second song titled 'Gold' by Kiiara from Album: Low Kii Savage (this one is with the copyright attribution by Ricis). The third song titled 'Rainy Day Games' by The Green Orbs from Album: Rayni Day Games.

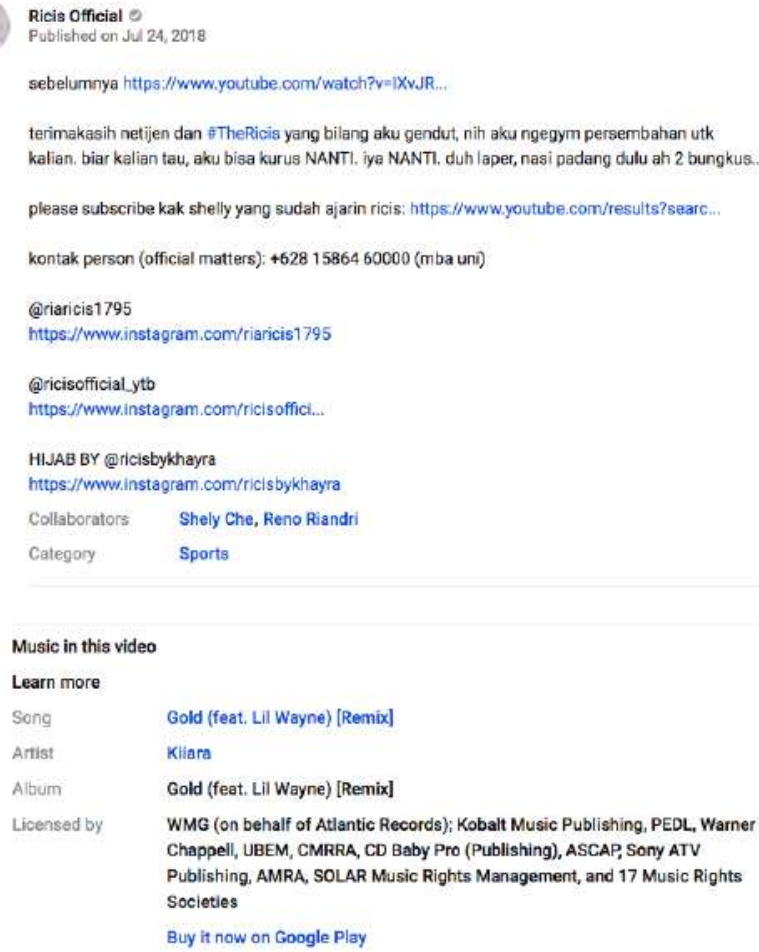

\section{Picture 2. Ria Ricis's Sample Video with Copyright Attribution}

The first Video of Arief Muhammad titled, "Main Bowling Bareng Followers," there are nine songs, and all have no copyright. Copyright on The first and second songs not identified. The third song is titled 'Bitten By Cupid' (By Slowfly feat Sture Zetterberg) from Album Golden Wonderland. The fourth 
song is undetectable, so is the fifth song. While the sixth song titled 'Red Light' by Lvly from Album: Way Way Back. The seventh song is undetectable, as is the eighth song. While the ninth song titled 'We're Falling in Love' by Snow DePart feat Jesper Pietersson from Album, Then you know It's Christmas - EP. In the second video of Arief Muhammad, there is one song included copyright by Youtuber, titled 'Hidden Paradise' by Eka Gustiwana (feat. Prince Husein \& Yessie Trivena). In the third video of Arief Muhammad, there are four songs, all of which do not include copyright. The first song titled: 'Endless Wave' (Reversed Twister Remix) by Kamaya Painters from Album: The Collected Works. Three other songs are unidentified titles.

Sebelum ke Sumba, kalian wajib nonton video ini dulul VLOGGG lengkap diupload weekend ini.

Song: Hidden Paradise - Eka Gustiwana (feat. Prince Husein \& Yessiel Trivena).

SUBSCRIBE: http://bitly/11vRLO7P

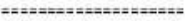

Alamat kirim-kirim:

Arief Muhammad

PO.BOX 7456

JKS 12014

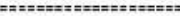

Contact Person: ariefmuh26@gmail.com

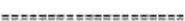

Akun sosial media gue yang lain:

TWITTER: http://twitter.com/Poconggg

ASK.FM: http://ask.fm/ariefmuhammad

PERISCOPE: @ariefmuhammad

INSTAGRAM: http//instagram.com/ariefmuhammad

\section{Picture 3. Sample Video of Arief Muhammad}

The first video of Gen Halilintar titled: " Pusing Muter Nendang Bola - Gen Halilintar FIFA World Cup Challenge" contains nine songs. From the nine songs, the first song was identified as 'Bang Bang Bang' by BIGBANG, taken from the album A. Second song is 'The Drum' by Seige, taken from album Boneshaker. All songs and back sounds are not included with copyright by the Youtuber. The second video of the Gen Halilintar titled: "Kegilaan Sebelum Performance" has 13 songs, all of it not listed with copyright. However, 
it showed that they are trying to avoid the copyright claim of the songs by all means. The background music is cut into an average of 5-6 seconds each (to avoid the demand for copyright violation?). However, in the comment column is found that the Youtuber has clarified that the video is re-uploaded. Some of the songs used before have claimed by the rightful owner (on Claim ID), so they replace the back sound music on that video. Some songs are identified, in the example the first song titled 'Havana' by Camila Cabello.

The ninth song titled 'Mysterious Conflict' by David Pires from Album: Life Is Changing. The tenth song is titled 'Let's Get It On' by Marvin Gaye. The eleventh song titled 'Highway To Hell' by AC / DC from Album: Highway To Hell. The twelfth song was unidentified, while the thirteenth background song took the footage of the Mission Impossible song. The third video of the Gen Halilintar with the title "Pake Kostum di Tempat Umum Kocaaak!!! Costume Challange Gen", has 14 background songs and one cover song. However, as usual, this Youtuber is very tricky to use a short piece of the songs. However, there is some song that identified, such as the second song titled 'Ben Damon' by Melter from Album: Five vs. Stars. The third and fifteenth (as a covering) titled 'Thunder' by Imagine Dragon. Then on the ninth song titled 'No Excuses' by Megan Trainor from Album: No Excuses.

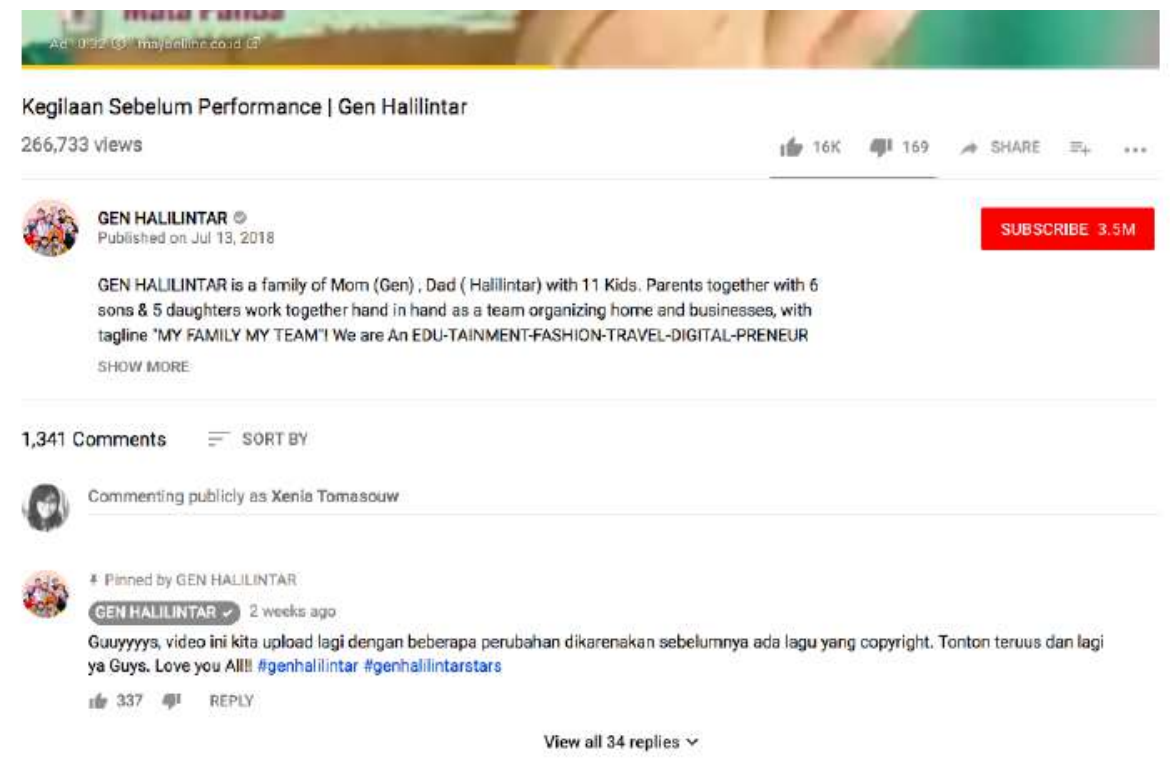

Picture 4. Gen Halilintar Video's Copyright Explanation 
The fifth Youtuber, Kevin Hendrawan, on his video titled "Ngabuburit The Series: Damai Itu Indah Episode 29 (Final)" is found to include attribution in the video description section. The background song used in this video is Original Soundtrack \#NgabuburitTheSeries by Althof Miraza explicitly created for this youtube series. In this case, the use of attribution has been done correctly in the form of a description. The second video of Kevin Hendrawan titled "Kaget Lihat Malin Kundang Asli Plus Bangkai Kapalnya Langsung di Padang" using eight back sound songs, with some that identified, such as the third song titled 'Toca's Miracle' by Coco Vs. Fragma from album DJ Ricardo! Pres. Out Anthems, Vol. 3. After that, 'La Princesa by Pedro El Flamenkito from the album La Princesa. The third song identified is La La (Singin 'Like)' by Elijah N. Feat. Ms. K from album Blogilates Summer Sweat Mix. From the eight songs used, three identified while others are not. The entire song does not use copyright attribution.

Meanwhile, in Kevin Hendrawan's third video titled "Short Escape: Jakarta Rasa Gili Trawangan.", the video used six background songs, with no copyright attribution attributed to the entire song. Some of the songs identified from this video are 'La La (Singin 'Like)' by Elijah N. Feat. Ms. K from the album Blogilates Summer Sweat Mix and 'La Princesa' by Pedro El Flamenkito from the album La Princesa which is a repetition of the previous video.

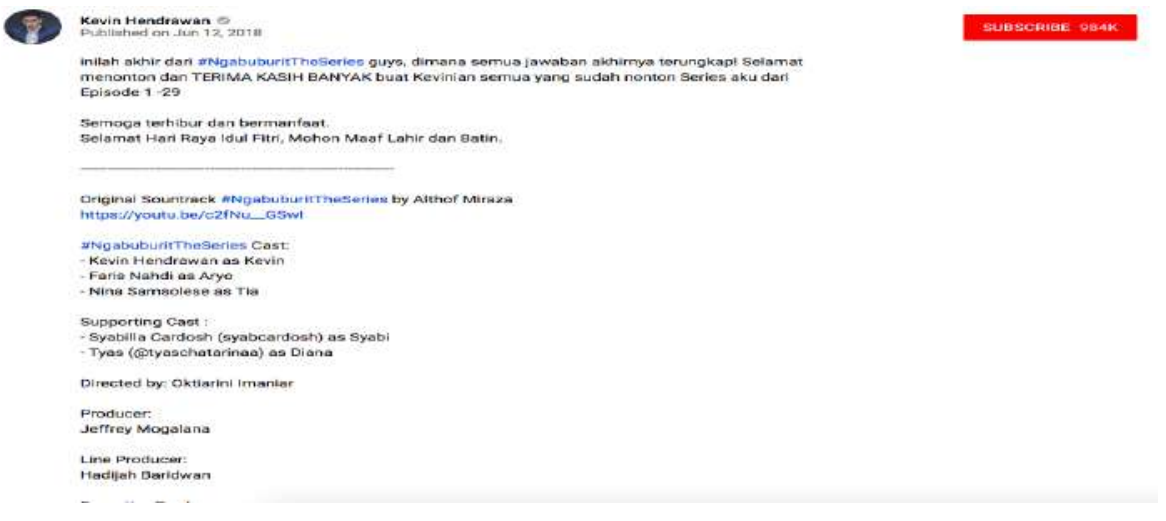

Picture 5. Kevin Hendrawan Attribution Sample on one of His Video

For the subjectivity discussion, the researcher sees that Youtubers even understand the global context of Youtube usage. However, in practice, they are not fully implementing global regulatory regulations, especially regarding 
copyright. On the other hand, the YouTube policy with Fair Use causes the YouTubers to use the regulation according to their "tastes" and subjectivity. The absence of sufficiently clear restrictions, making this rule seem indirect to do "omission" on copyright violation. Fair Use nevertheless is the grey area in the problem of the use of background music and songs copyright.

In addition to this, it seems that the YouTube policy in enabling Content ID Claim and Copyright Straight Basic applied in some videos. It is seen from the replacement of background songs performed by Gen Halilintar on one of their videos, as discussed above. One of the things that became researchers' concerns is the use of a background song. With a short time as Gen Halilintar did on their videos, is there any special regulation for the duration of a song on YouTube so that its use spared from Copyright Claim? Alternatively, it is possible just because of the lack of attention on YouTube or the rightful owner of the song put on it that made it possible to avoid.

Subjected to the use of free content, until the end of this research, no visible attribution provided by the Youtuber or any other that indicates if they use free content as suggested by YouTube on its site. There is also no use of another kind of attribution, such as Creative Commons in the description section of the Youtuber videos. It is interesting when Youtubers do not use attribution when using other people's content, but they also not using free content provided by Google. It is doubtful if we give the assumption that they do not understand or have knowledge about this. However, it is exciting to study further why (the reason behind) they do not provide attribution and also why they choose not to use available free content.

\section{Conclusion}

This research shows that Youtuber has run the agent of change function that is different from mainstream media, or in this case, television. They produce content with divers variety and build communication with their subscribers reasonably well. Two-way communication between the Youtuber and their audience shows how the difference them with the mainstream media as television. While in terms of content and subjectivity, especially in regards to the use of songs and music as background, it appears that Youtubers generally do not run attribution according to copyright rules globally. It also shows that understanding the context imposed by YouTube has not been thoroughly done by the Youtuber. Content ID Claim, Copyright Basic Strike, and Fair 
Use are still not run wholeheartedly. It is clear that the Youtubers awareness of respecting copyrights of musicians and songwriters, including singers, is relatively less on Youtuber Indonesia. A firmer legal approach from Youtube managers would be significant to influence Indonesian Youtuber behavioral patterns. For further research, researchers suggest deepening the study of strengthening copyright law enforcement and its development from various aspects, especially communication.

\section{References}

Adding Music. (2018, July) Accessed from https://creatoracademy.youtube. $\mathrm{com} / \mathrm{page} / \mathrm{lesson} /$ add-music?hl=en

Ayuwuragil, K. (2018, April 06). Youtube Jadi Aplikasi Media Paling Populer di Indonesia. CNN Indonesia. Accessed from https://www.cnnindonesia. com/teknologi/20180406202852-213-288967/youtube-jadi-aplikasimedia-paling-populer-di-indonesia

Bouvier, G. (2015). What is a discourse approach to Twitter, Facebook, YouTube and other social media: connecting with other academic fields?. Journal of Multicultural Discourses, 10:2, 149-162, DOI: $10.1080 / 17447143.2015 .1042381$

Filardo-Llamas, L. (2015). Re-contextualizing political discourse: An analysis of shifting spaces in songs used as a political tool. Critical Discourse Studies, 12(3), 279-296. DOI: 10.1080/17405904.2015.1013478

Gannon, V., \& Prothero, A. (2018). Beauty bloggers and YouTubers as a community of practice. Journal of Marketing Management, 34(7-8), 592-619 DOI:10.1080/0267257X.2018.1482941

García-Rapp, F. (2017). Popularity markers on YouTube's attention economy: the case of Bubzbeauty. Celebrity Studies, 8(2), 228-245. DOI: $10.1080 / 19392397.2016 .1242430$

Google Support Youtube Answer. (2018, July) Accesed from https://support. google.com/youtube/answer/2814000?p=c_strike_basics\&hl=en-GB

Google Support Youtube. (2018, July) Accesed from https://support.google. com/youtube/answer/6013276?hl=en-GB

Guo, L., \& Lee, L. (2013). The critique of YouTube-based vernacular discourse: A case study of YouTube's Asian community. Critical Studies in Media 
Copyright issue on music back sound usage by ...(Xenia Angelica Wijayanto,Lestari Nurhajati)

Communication, 30(5), 391-406. DOI: 10.1080/15295036.2012.755048

How Much Money do YouTubers Make per View. (2018, July) Accessed from https://medium.com/swlh/how-much-money-do-youtubers-make-perview-2390141a4922)

Laing, D. (2012). Copyright in the Balance: Notes on Some 21st-Century Developments. Popular Music and Society, 35(5), 617-627. DOI: 10.1080/03007766.2012.709663

Praditya, D. (2018, May 18). 3 Fakta Menarik dari Riset Google tentang Perkembangan YouTube di Indonesia. Accessed from https://id.techinasia.com/faktaperkembangan-youtube-di-indonesia

Riswari, A.A. (2018, May 10). Arief Muhammad Salah Satu Anak Bangsa yang Terkenal di Kancah Internasional. Good News From Indonesia. Accessed from https://www.goodnewsfromindonesia.id/2018/05/10/ariefmuhammad-salah-satu-anak-bangsa-yang-terkenal-di-kancah-internasional

Rolando, S., Taddeo, G., \& Beccaria, F. (2016). New media and old stereotypes. Images and discourses about drunk women and men on YouTube. Journal of Gender Studies, 25(5), 492-506. DOI: 10.1080/09589236.2015.1041462

Thibeault, M. D. (2012). From compliance to creative rights in music education: Rethinking intellectual property in the age of new media. Music Education Research, 14(1), 103-117. DOI: 10.1080/14613808.2012.657165

Tolson, A. (2013). A new authenticity? Communicative practices on YouTube. In Self-Mediation (pp. 93-106). Routledge. DOI: 10.1080/17405904.2010.511834

Triyanto. (2017). Copyright Law Enforcement: An Indonesia Case Study. Journal of Intelectual Property Rights Vol 22, pp 276-284.

Vergani, M., \& Zuev, D. (2011). Analysis of YouTube Videos Used by Activists in the Uyghur Nationalist Movement: combining quantitative and qualitative methods. Journal of Contemporary China, 20(69), 205-229. DOI: $10.1080 / 10670564.2011 .541628$

Youtube Copyright Protection. (2018, July) Accesed from https://www.youtube. $\mathrm{com} / \mathrm{intl} / \mathrm{en}-\mathrm{GB} / \mathrm{yt} / \mathrm{about} /$ copyright/fair-use/\#yt-copyright-protection

Yulistara, A. (2018, February 25). 10 YouTuber Indonesia dengan Penghasilan Miliaran Rupiah. CNBC Indonesia. Accessed from https://www. cnbcindonesia.com/lifestyle/20180225163251-33-5380/10-youtuberindonesia-dengan-penghasilan-miliaran-rupiah 
Journal of Social Studies (JSS), Volume 16, Number 2, 2020: 137-156 